\title{
Approach and impact of a participatory process for the reorganization of irrigation management: a case study in Indonesia
}

\author{
Bruno Lidon ${ }^{1,2}$, Jean-Marie Lopez ${ }^{1,2, *}$, Hendri Sosiawan ${ }^{3}$, Budi Kartiwa ${ }^{3}$, Bernard Triomphe ${ }^{2,4}$, \\ Jean-Yves Jamin ${ }^{1,2}$, Stefano Farolfi ${ }^{1,2}$, Robin Bourgeois ${ }^{2,5}$ and Nicolas Becu ${ }^{6}$ \\ ${ }^{1}$ CIRAD, UMR G-EAU, 34398 Montpellier, France \\ ${ }^{2}$ Univ Montpellier, Montpellier, France \\ 3 IAHRI, Bogor, Indonésie \\ ${ }^{4}$ CIRAD, UMR Innovation, 34398 Montpellier, France \\ ${ }^{5}$ CIRAD, UMR ART-Dev, 34398 Montpellier, France \\ ${ }^{6}$ CNRS, UMR 7266, La Rochelle, France
}

\begin{abstract}
The paper emphasizes key lessons learnt about a research intervention implemented from 2006 to 2009 to solve water access conflicts in the Klaten irrigated rice production area (Central Java, Indonesia). To make stakeholders' involvement easier, to empower them and build their capacity, action research was carried out according to a flexible and iterative approach. Each step involved a cycle of diagnosis, action planning, implementation, evaluation and learning. The paper shows the need to facilitate the functioning of a multi-stakeholder platform through the creation of a monitoring mechanism in order to ensure, on the one hand, stakeholders' involvement within the action-research process and on the other hand, foster brainstorming and mutual learning among participants. The paper brings to the fore the usefulness of assessing findings of multidisciplinary and participatory appraisals through modeling and geo-referenced mapping tools in order to facilitate collective learning, negotiation and technical and institutional innovation. Finally, through the assessment of the evolution of the farmers' association, whose creation was a project outcome, the paper reflects about key issues and key steps that have contributed to carry on successfully the developed methodology.
\end{abstract}

Keywords: conflict / water access / irrigation / participatory approach / multi-stakeholders / Indonesia

Résumé - Approche et impacts d'un processus participatif pour la réorganisation de la gestion d'un périmètre irrigué : étude de cas en Indonésie. L'article illustre les enseignements tirés d'une rechercheintervention conduite entre 2006 et 2009 dans le bassin rizicole irrigué de Klaten (Java, Indonésie) pour résoudre les conflits d'accès à l'eau et mettre en œuvre un plan d'action. Afin de faciliter l'implication des différents acteurs et, parallèlement, de renforcer leur autonomie et capacité d'intervention, des actions de recherche ont été réalisées sur la base d'une approche itérative et flexible. Ainsi, chaque étape a été développée selon un cycle : diagnostic, plan d'action, mise en œuvre et évaluation des actions, et enseignements retenus. L'article insiste sur la nécessité de créer et de faciliter le fonctionnement d'une plate-forme multi-acteurs et d'un comité de suivi afin de garantir l'implication des acteurs dans la démarche et d'initier un groupe de réflexion parmi les participants. En fonction de la question de recherche posée et de son échelle physique et organisationnelle, il met en avant l'utilité d'analyser les résultats des diagnostics participatifs et multidisciplinaires via les outils de modélisation et de représentation cartographique géo-référencée, afin de faciliter l'apprentissage collectif, la négociation et l'innovation technique et institutionnelle. Enfin, en se référant à l'évaluation de l'évolution de l'association d'irrigants dont la création a été un résultat du projet, il discute les étapes clés qui ont contribué au succès de la méthodologie développée.

Mots clés : conflit / accès à l'eau / irrigation / approche participative / multi-acteurs / Indonésie

*Corresponding author: jean-marie.lopez@cirad.fr 


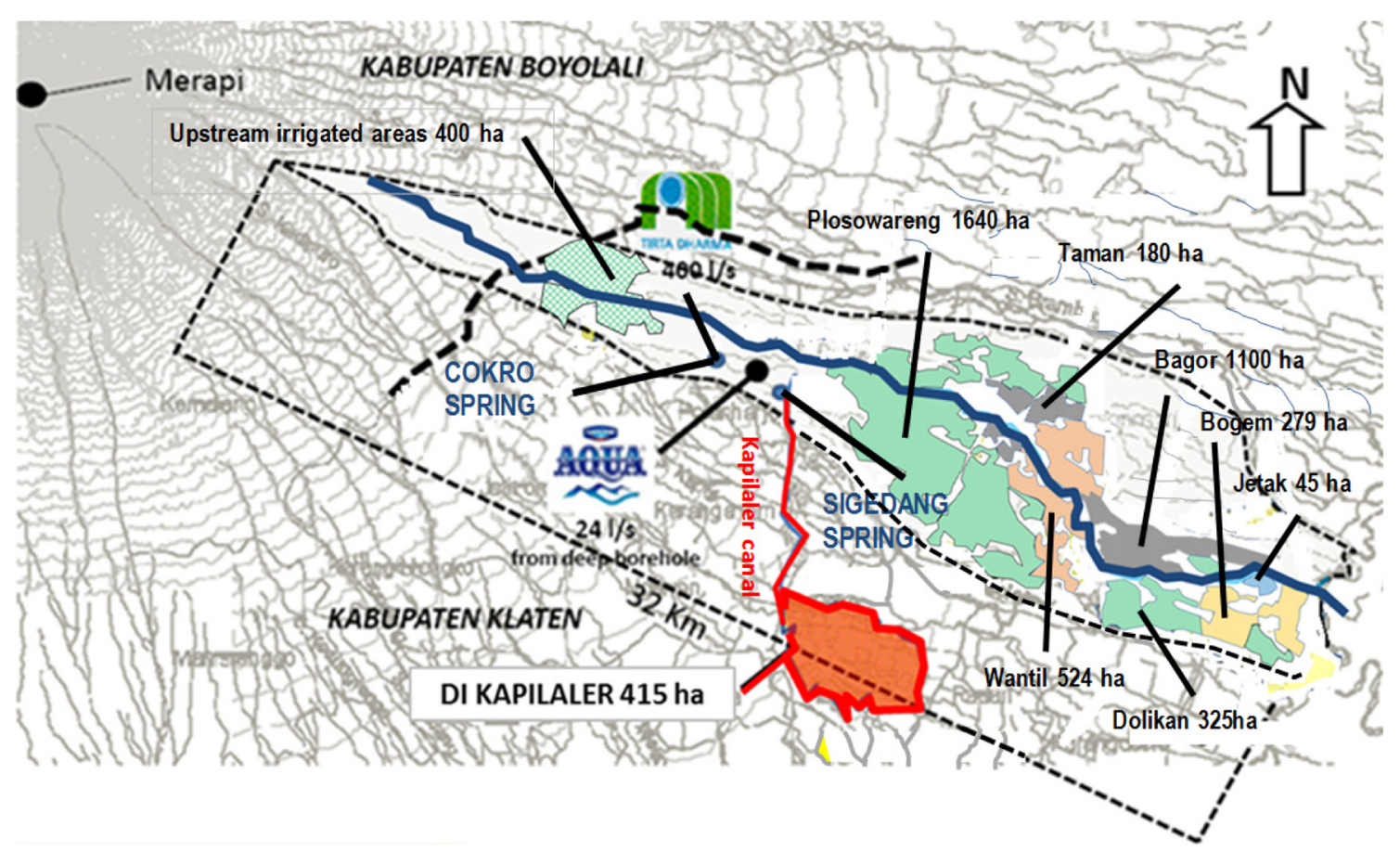

Fig. 1. Map of Pusur Watershed.

Fig. 1. Carte du bassin versant de Pusur.

\section{Introduction}

Despite an average yearly rainfall of $2000 \mathrm{~mm}$, some parts of Central Java Province (Indonesia) are experiencing since the 1990s limited access to water for irrigation communities and private households (Purwanti and Jaji, 2006). This is partly due to a fast population growth and rapid economic development leading to competing consumptive water uses between industry (5\%), state-managed domestic water suppliers $(12 \%)$ and agriculture sector (83\%) (source: Badan Pusat Statistik Kabupaten Klaten, 2018). The Kali Pusur watershed, in Klaten regency (Fig. 1), is illustrative of such a situation. In 2005 , the growing water scarcity in the Kapilaler rice irrigated scheme resulted in a dispute over water allocation between upstream and downstream farming communities. They finally turned against non-agricultural water users considering that their increasing water withdrawals are at the origin of the dispute. It ended up accusing the 2 years old Danone-Aqua bottled water plant launched in 2003 of being responsible for the water scarcity.

Research intervention began in 2006 in response to a request from Danone-Aqua to identify and develop solutions to "increase water productivity". Considering, on the one hand, that multipurpose water use is becoming one of the main worldwide challenges, and, on the other hand, that the terms of reference defined by Danone-Aqua were in line with their own ethical charter, French and Indonesian partners agreed to conduct collaborative research activities. They were implemented from 2006 to 2009 by a multi-disciplinary team involving scientists from the Centre de cooperation Internationale en Recherche Agronomique pour le Développement (CIRAD), the Indonesian Agriculture Agency for ResearchDevelopment (IAARD), the Gadjah Mada University - Center for economic democracy studies (UGM-Pustek) and its Department of sociology, in close collaboration with the technical departments of the Klaten Regency.

The paper presents the "community visioning and strategic planning" process (Bryson et al., 2009) that allowed stakeholders to successively investigate roots of water conflicts and develop new rules and strategies for improving water sharing. It also reviews the key lessons learnt as identified during the impact assessment carried out in 2014 (Lidon et al., 2017).

After presenting the study site (Sect. 2), the methodology is introduced (Sect. 3) in terms of rationale and approach followed, then the results are detailed (Sect. 4) and conclusions and recommendations are provided (Sect. 5).

\section{The study site}

The Pusur watershed is a sub catchment of the Dengkeng River, situated on the slopes of Mount Merapi volcano (Fig. 1). It extends over two Regencies: Boyolali (upstream part) and Klaten (downstream part) (Lopez et al., 2011).

Water resources are shared between around 12000 smallholders on the one hand, and water companies on the other hand. The irrigated system comprises the Kapilaler irrigated area $(415 \mathrm{ha})$, supplied by Siguedang spring through a $7 \mathrm{~km}-$ long feeder canal, and 2 clusters of irrigated schemes, supplied by Kali Pusur stream. The first one includes a dozen small irrigated area located upstream of Cokro spring ( 400 ha total area) while the second one comprises 7 irrigated areas (3400 ha total area) downstream. While the cropping system in the first cluster includes 2 successive crop cycles (rice mainly followed by a non-rice crop) grown during rainy season, in the other areas it is mainly based on rice monoculture, including a third cycle in dry season when possible. 
The extent of the multipurpose water uses is a specific feature of Kali Pusur watershed. There are two main nonagricultural water users that operate according to formal agreement: a semi-owned state water provider (PDAM Perusahaan Daerah Air Minum), and a commercial bottled water company (Danone-Aqua, a subsidiary of the Danone group). Since $1950 \mathrm{~s}$, PDAM extracts around $400 \mathrm{~L} / \mathrm{s}$ directly from Cokro Spring $(1400 \mathrm{~L} / \mathrm{s})$. In contrast, Danone is only operating since 2003. It extracts around $40 \mathrm{~L} / \mathrm{s}$ from a borehole (self-flowing) located just several hundred meters from Sigedang spring. It discharges $15 \mathrm{~L} / \mathrm{s}$ of surplus water into the Kapilaler feeder.

During the dry season, the water supply of the Kapilaler scheme basically comes from the Siguedang spring flow $(225 \mathrm{~L} / \mathrm{s})$ that numerous water intakes and conveyance losses reduce by around $40 \%$. Regarding the other irrigation schemes, which are supplied through diversion weirs along Kali Pusur, their water resource relies on Cokro spring (total discharge: $1400 \mathrm{~L} / \mathrm{s}$, available discharge: $1000 \mathrm{~L} / \mathrm{s}$ ) that contributes to more than $90 \%$ of the water flow during the dry season. Those scarce water resources result in a water availability that does not exceed $0.3 \mathrm{~L} / \mathrm{s} / \mathrm{ha}$ in dry season, while rice demand is around $1.2 \mathrm{~L} / \mathrm{s} / \mathrm{ha}$.

Since the 1987 irrigation management turnover program, water users' associations (WUAs), which are organized by village in Klaten Regency, manage the irrigation facilities in liaison with the decentralized water department of the Ministry of Public Works (Vermillion et al., 1999). However, the difficulties in implementing this reform result in diluting responsibilities and neglecting maintenance (Bruns and Helmi, 1996), whereas empowerment of WUAs, despite their formal legal status, is still confronted with the need to strengthen their capacities to play their expected role.

Within this context, since the state sugar sector shut down in 1990s, many farmers converted sugar cane fields to paddy, despite numerous warnings from extension service regarding the need to cultivate more non-rice crops during dry season to balance water demand with water availability.

The resulting water scarcity engenders water delivery practices favoring upstream areas. This results in water access inequity jeopardizing irrigated farming. It also affects villagers' domestic supply, as an increasing number of farmers exploit surface wells for supplementing irrigation.

In the early 2000 s, the extension of rice-growing areas during dry season in place of sugar cane, which has lower water requirement during this period coinciding with its ripening phase, increased water demand and caused conflicts between WUAs. It particularly hit the Kapilaler area where stakeholders had set up a conciliation forum, the "Forum Kapilaler Komunikasi", to enforce rights to water along the feeder canal. Conflicts between WUAs turned into clashes with water companies accused to be the root cause of the water crisis. In 2005, at a moment of heightened tensions and controversies linked to the discussion of a new national water law, which was perceived as a step into privatizing the water sector (Al'Afghani, 2006), Danone-Aqua became a scapegoat for farmers' groups and NGOs that called for the closure of the plant.

To ease tensions, sustain its business and ensure its brand image, in 2006 Danone-Aqua decided to reinforce its Corporate Social Responsibility by funding a program aiming at identifying and developing technical and organizational changes able to increase farming productivity and alleviate water shortages.

\section{Methodology}

Research activities started in 2006. Under the tense situation prevailing at the time, a primary aim was to contribute to preventing new conflicts. Thus, involving stakeholders in the research process was considered essential.

\subsection{Building on three main approaches}

The involvement of local stakeholders in a participatory process to identify strategies for the management of water resources refers to a number of different but interlinked and complementary approaches.

The first approach is the theory of the commons' governance (Ostrom, 1990). It states that local stakeholders can develop their own rules for the management of common pool resources (CPR), and that those rules have a better chance to be effective, efficient, and equitable than rules imposed from outside; setting a system of property rights may avoid the depletion of the CPR called "tragedy of the commons" by Hardin (1968).

The second approach is participatory action research (PAR) (Reason and Bradbury, 2001; Faure et al., 2010). PAR comprises a family of methodologies aiming at pursuing action and research outcomes at the same time. One of the key characteristics of PAR is collaboration (or partnership) among multiple stakeholders, which enables mutual understanding and consensus, democratic decision-making and common action (Oja and Smulyan, 1989). Another crucial concept of PAR is social change, through a process of "learning by doing". In a PAR project, people learn through an active adaptation of their existing knowledge in response to their experiences with other people and their environment. Hermeneutic spirals (Gummesson, 1991) are put in place, with each turn of the spiral building on the understanding of the previous turn.

The third approach is participatory modelling (PM). Computer models can provide a general and flexible framework to study how water and river basin systems behave and how these systems may react to different policy choices (Voinov and Bousquet, 2010). They can also contribute to the involvement of citizens and other stakeholders, by allowing a range of "what-if" scenarios to be tested simply and rapidly (Brugnach et al., 2007). PM can take many forms (conceptual, practical, and formal) and can serve many needs (Magnuszewski et al., 2004). However, the common purpose of this approach is to increase understanding of the complex socioecological systems across all levels and sectors of society by combining knowledge of different types about the system contributed by the various stakeholders. PM is characterized by the fact that stakeholders are directly involved into the design of the models in order to ensure that the models are aiming at the problems and stakeholders are able to use them (Horlitz, 2007). This form of participation creates a forum in which "experts may learn about different aspects of the usefulness of their tools in a policy process" (Jonsson and Alkan-Olsson, 2005). 

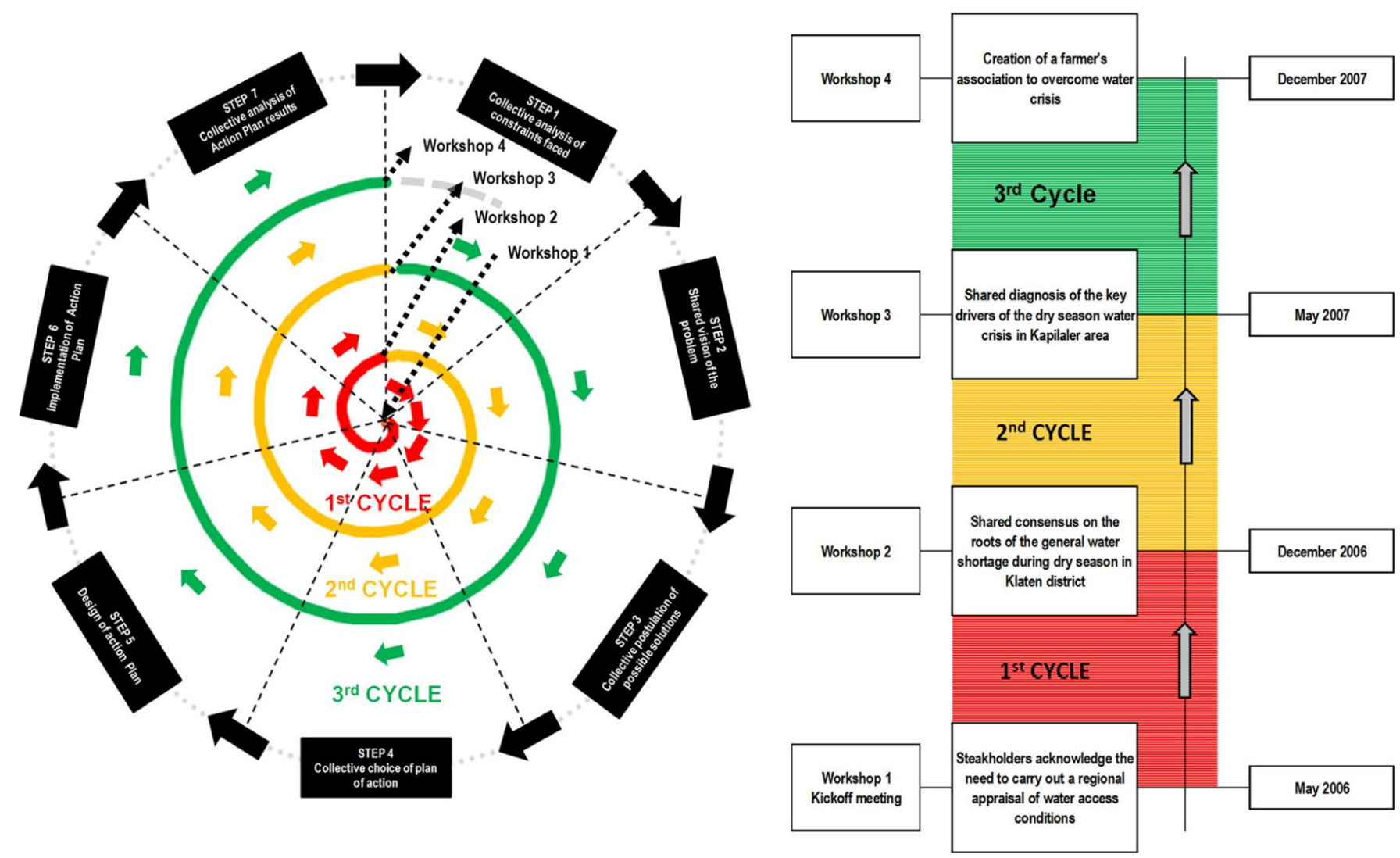

Fig. 2. Key steps and cyclic scheduling of "community visioning and strategic planning process". Adapted from: Catroux (2002), McNiff and Whitehead (2002), Costello (2003), and Lesser and Stork (2001).

Fig. 2. Étapes clés et programmation cyclique du "processus de vision communautaire et de planification stratégique».

The Companion Modeling (ComMod) approach (ComMod, 2003; Étienne, 2012) represents a particular approach to PM where the researchers' modeling process and the stakeholders' negotiation process are conducted in close interaction. In ComMod, simulation accompanies an iterative research process consisting of repeated cycles of 'field workmodelling-simulation-field work'.

\subsection{The Community visioning and strategic planning process}

The approach used in this study is inspired by these three scientific approaches, and is synthesized in the "community visioning and strategic planning process" (CVSP) as defined by Bryson et al. (2009) that we developed based on Catroux (2002), McNiff and Whitehead (2002), and Costello (2003) (Fig. 2). It consists of a reflective process of progressive problem solving by stakeholders considered as a community of practice (Lesser and Stork, 2001) to improve the way they address issues and solve problems. This approach aims at shedding light on some of the key factors that several authors (Wade and Chambers, 1980; Chambers, 1988) stressed as making part of the 'blind spot' in the management of the main irrigation canal systems. More precisely, it addresses issues such as the main systems operation in practice, and how to enhance the performance of canal irrigation through improved working of the administrative hierarchy, which operates the canals.
Each phase of the approach is designed according to changes generated by the previous one. Each research cycle consists of 7 steps. At this point, the problem is re-assessed and the process begins another cycle. Each cycle includes an action program that structures stakeholders' involvement and multidisciplinary intervention in so far as it defines:

- specific tasks (what will be done and by whom);

- time horizon (when will it be done);

- resource allocation (what specific funds and human resources are available for specific activities).

In our case study, the process was pursued until a set of technical and organizational changes contributing to ensure that water access equity and enhancing economic water use efficiency could be identified and implemented by stakeholders.

By turning stakeholders into actors in the research process, this approach concurrently allows ensuring to take into account critical issues for change: empowerment and capacity building of stakeholders through co-learning.

To implement, monitor, analyze activities, and accompany stakeholders in making a commitment and taking decisions, the research process relies on multi-stakeholder platforms, community workshops, monitoring committees (MC). It also relies on the use of interactive simulation modeling tools allowing all parties to visualize how benefits could be generated from technical and organizational changes. Stakeholders are 
involved in multidisciplinary and participatory rapid appraisals used to develop, calibrate and validate the models, in order to raise their willingness to engage in scenario analysis produced by models that they have contributed to create.

The research team volunteered to play the role of facilitator of the CVSP process, due to the combination of expertise skills and facilitation capacity it offered (Bourgeois et al., 2008). The fact that Danone-Aqua funded the research actions gave rise to reasonable doubts about the impartiality and independence of the results. Therefore, monitoring committees involving representatives of the main stakeholders were formed to ensure transparency of the facilitation and to legitimize the role played by the research team in the eyes of the other stakeholders.

Multi-stakeholder platforms were selected by stakeholders' community during workshops open to a wider public that were held within the framework of each research cycle. They were composed of representatives of WUAs, farmers' groups, private companies and public authorities, in order to bridge the gap between grass-roots action and top-down policy, by bringing the actors together for brainstorming on the ins and outs of the water crisis.

\subsection{Assessing ex post the impact of research}

The ex post impact of the research was assessed using the participatory evaluation method "Impress" developed by CIRAD (Temple et al., 2016). Derived from the "impact pathway" approach (Douthwaite et al., 2003), it consists in mapping the inputs, outputs, outcomes and impacts produced, and then identifying causal links through a contribution analysis (Mayne, 2001). Stakeholders take an active role in identifying the impacts, quantifying them, and then pointing out and validating the causal links.

The impact assessment process was carried out through five phases:

- the inception phase consisted in drafting hypothesis for potential impacts and pathways, and drafting an innovation story and timeline;

- a workshop with stakeholders was conducted to allow them to express what changes they experienced and what were the tangible effects of these changes, in order to define a series of impact indicators;

- primary qualitative and quantitative information about the impact indicators, the innovation story and the causal relationships leading to the identified impacts, was then gathered through focus groups and semi-structured interviews;

- the resulting valuation of the impacts and research outcomes led to identify the impact pathways that corroborate the innovation story though the opinions and statements of institutional players;

- a participatory validation of the findings was conducted during a workshop involving all stakeholders.

\section{Results}

The research outcomes illustrate how the progress of stakeholders' community visioning and the co-learning process have both contributed to gradually co-develop project activities and produce outcomes.

\subsection{Shared consensus on the roots of water crisis in a post conflict}

The first CSVP cycle started with a one day kick-off workshop (Workshop I, May 2006), entitled "Building together a vision of water resources management towards effective agricultural systems in the Klaten Regency". Its 130 participants included representatives of water users' groups, NGOs and public and private companies, as well as regional and local governmental decision makers, representatives of technical departments and subject matter experts. Its main objective was to tackle water crisis issues through an integrated water resource management approach aimed at overriding participants' rigid ideological and conflicting postures.

Participants concluded that lack of data and questionable information made difficult a thorough assessment of the roots of water crisis. They also agreed that the research team and Klaten technical departments would carry out a regional appraisal of water access conditions, and that a monitoring committee would overlook the findings.

The ensuing multidisciplinary and participatory rapid appraisal was conducted in 50 irrigated schemes around Mount Merapi to assess the adequacy of water supply, using the relative water supply index method (Perry, 1996).

The appraisal showed that all these schemes faced water constraints during dry season that restricted farming activities over $50 \%$ of their surface. It also revealed that water resources were significantly decreasing during dry season without any significant relationship with the rainfall patterns. Although it was noticed that the origin of the water resource (spring, stream, river...) was an explanatory factor, the fact that rice was the dry season dominant crop was found to be the main factor driving water shortage. It was also shown that water shortage most often resulted in unequal water sharing favoring the schemes upstream along the watercourse, and, within irrigated areas, their upstream parts.

Finally, unequal water sharing was shown to cause a higher occurrence of water shortage in the downstream areas.

Stakeholders interpreted this situation as being the combined result of damaged hydraulics structures, weak coordination of actors, disruptive cropping calendars, increased multi-purpose water uses and environmental degradation. They linked these problems with the tricky enforcement of the irrigation management transfer, and acknowledged that the dry season water crisis was a common issue in the whole Klaten area.

\subsection{Shared diagnosis of the key drivers of the water crisis}

The second cycle of the CVSP process started with a workshop to debate the results of the participatory appraisal. The multi-stakeholder platform members discriminated 3 categories of key drivers of the water crisis: (i) weak water management, (ii) availability of water resource, (iii) funding and political concerns. The participants pointed out the deterioration of the irrigation networks due to their bad maintenance, the non-respect of water sharing rules, increase of water thefts and weak synchronization of cropping 
calendars. They mostly attributed the decreasing trend in water resource availability to environment degradation in the upstream part of the watershed while stressing lack of transparency on water resources data and water allocation for non-agricultural purposes. Finally, they questioned the irrigation sector policy of transferring maintenance costs to water users, while not channeling to the agriculture sector the funds coming from water licenses.

This shared diagnosis led participants to conclude that technical and organizational changes had to be addressed through a holistic approach. Confronted with the complexity of approaching water management at the watershed level, platform members decided to focus on the Kapilaler irrigated area ( $415 \mathrm{ha}$ ) as it had been the "hot spot" during the 2005 clash.

The related action plan aimed to carry out a diagnosis of the underlying causes of the water crisis, in order to identify potential solutions for improving water access equity. A multiscale water balance model of the Kapilaler irrigation system was developed using the CORMAS software (Becu et al., 2003 ) in order to take into account irrigation practices. The monitoring committee organized meetings with the Kapilaler water users to validate the modeling outputs, using maps of the adequacy of water supply to crop requirement at the irrigation block scale (Fig. 3).

\subsection{Creation of a farmers' association to overcome water crisis}

A third CVSP cycle was launched at a new workshop held in Klaten on May 2007. The modeling tool produced water management scenarios presented in maps allowing participants to express their perceptions. The ensuing discussions with platform stakeholders showed that they all agreed that the magnitude of water losses along the irrigation network, the rice acreage and the non-enforcement of water sharing rules were all causes of the high water access inequity that increased the social consequences of water shortage. They concluded that dealing with water crisis required changes to:

- improve the network conveyance efficiency;

- guarantee a delivery flow around $0.6 \mathrm{~L} / \mathrm{s} / \mathrm{ha}$ at the entry point of the Kapilaler irrigation network during the dry season to meet corn or vegetables water requirements;

- establish new irrigation scheduling based on the surface area to be watered;

- give water users' community the means to enforce water management rules.

Discussions on this last point emphasised the current difficulties in enforcing operation and maintenance decisions taken by the Forum, as their implementation was mainly depending on the WUAs of the 17 villages.

Considering the inconsistency between the necessary institutional capacities to improve management and the informal status of the Forum, participants also suggested to give the Forum a legal status.

The related action program focused on:

- assisting water users' community in defining the new status and missions of the Forum;

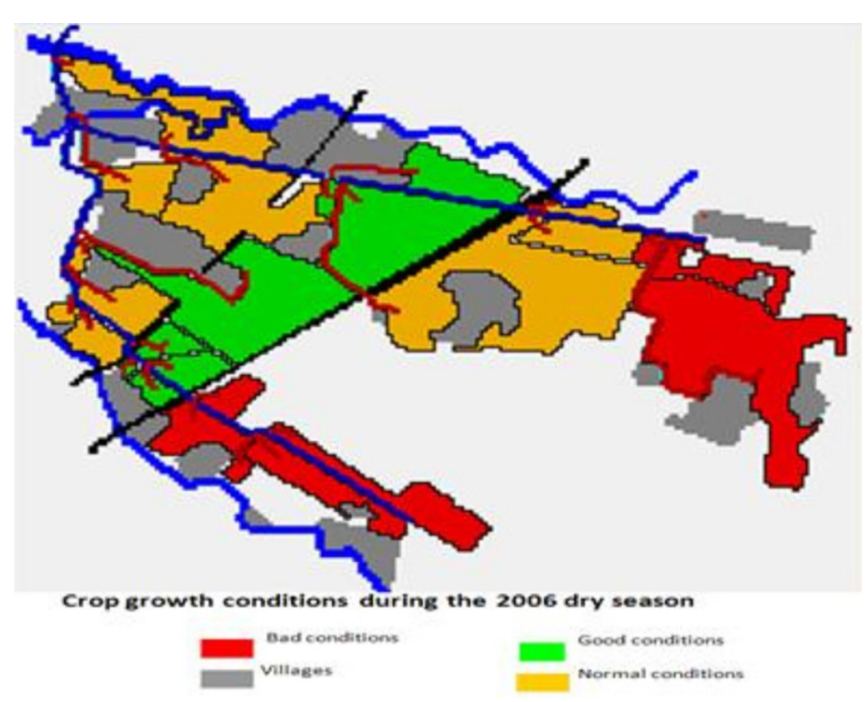

Fig. 3. Simulation under CORMAS of the crop growth conditions in Kapilaler during 2006 dry season.

Fig. 3. Simulation sous CORMAS des conditions de croissance des cultures à Kapilaler pendant la saison sèche de 2006.

- validating the technical and economic feasibility of corn cropping through on-farm tests;

- defining and implementing a maintenance policy.

Several meetings were needed to reach a consensus regarding the mission and status of the Forum. Water users eventually decided to create an association having the double responsibility of managing operation and maintenance, and developing competitiveness of agricultural activities. This led to change the Forum into a legalized non-profit association: FK PADIKA. The association has an executive board of 9 members mandated by representatives of water users and farmers (assembly of 60 people) from 17 villages ( $900 \mathrm{ha}$, 2300 smallholders) and 5 dedicated units: Water management, Security, Agriculture, Economy, and Public Communication.

The facilitating team helped FK PADIKA to develop its first yearly action plan. It focused on activities aimed at strengthening its legitimacy within water users' community and at building the capacity of its members. Besides trainings of board members in organization management, it mainly consisted of (i) disseminating information on corn cropping profitability through the organization of farmer field day events, and (ii) defining and starting implementation of a maintenance policy through rehabilitation works sponsored by Danone-Aqua.

The subsequent participatory appraisal of the outcomes of this action plan identified the need to strengthen the financial sustainability and the economic role of FK PADIKA. Platform members also acknowledged CSVP as a useful way to tackle water crisis: they therefore suggested scaling out the CSVP process in the other irrigated schemes located along the river.

\subsection{Impact of FK PADIKA creation}

Since the creation of FK PADIKA, the dry season cropping system substantially changed: corn acreage increased from 70 
Area cultivated in Kapilaler during 2008 dry season

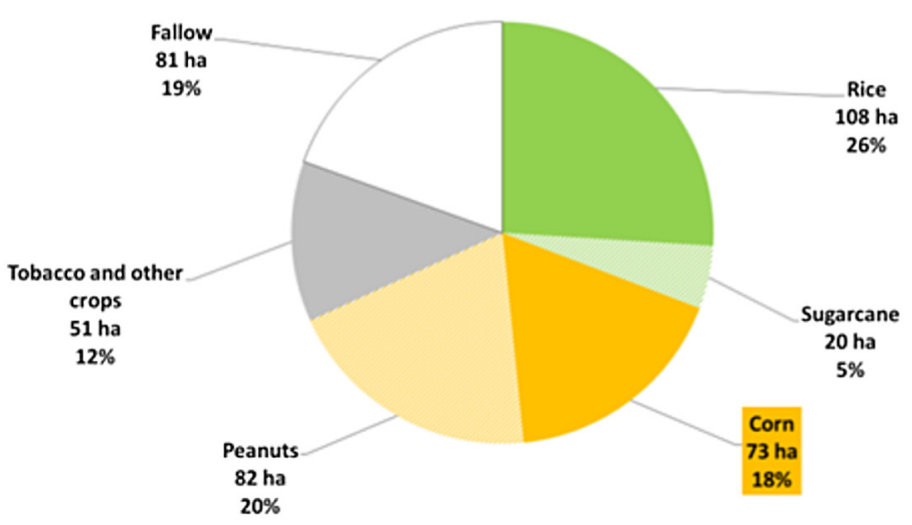

Area cultivated in Kapilaler during 2014 dry season

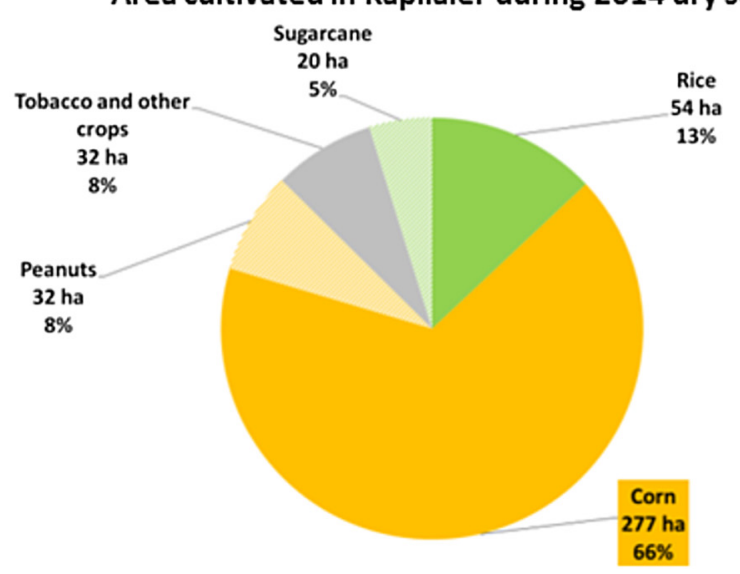

Fig. 4. Comparison of dry season cropping system in 2008 (creation of FK Padika) and 2014 (6 years later at the date of the impact assessment survey).

Fig. 4. Comparaison des systèmes de culture de saison sèche en 2008 (création de FK Padika) et 2014 (6ans après, à la date de l'enquête d'évaluation d'impact).

to 280 ha, while rice area reduced from 110 to 50 ha and fallow almost disappeared (Fig. 4).

As documented by the water users' perception, FK PADIKA played a major role in enhancing water delivery, which in turn improved water access in the whole irrigated area. However, as acknowledged by FK PADIKA members, part of this improvement was assignable to Danone-Aqua who contributed to subsidize maintenance works and the water police.

Water demand continues to outstrip supply because of increased dry season crops acreage; consequently, farmers have to pump one third of water demand from the shallow water table to produce corn in a cost-effective way.

Farmers agree that the improved water access allowed them to increase their income, as far as they have the cash needed to finance pumping costs. On $16 \%$ of the surface area, farmers that previously benefited from a privileged water access must now pump. This results in a differentiated impact depending on financial capacity of farmers and previous access conditions.

FK PADIKA was created in line with the principle of subsidiarity (Bourgeois, 2008): activities should be undertaken at levels where they can best be handled. However, within the frame of the government policy aiming at strengthening capacity of water users' associations, a district organization, grouping water associations of the southern part of FK PADIKA area, was created in 2012. This contributed to feed a controversy on the legitimacy of FK PADIKA as an organization coordinating activities of water users' associations. Within this context, FK PADIKA had not enough institutional recognition to gain access to government support and remained reliant on funding by Danone-Aqua.

Finally, in 2015, agri-business activities promoted by its economy desk allowed FK PADIKA to gain institutional recognition and support from government agencies through the National Program for Community Empowerment. By obtaining a complete kit of mechanical agricultural equipment, FK PADIKA got the capacity to provide service for its members, ensure its financial self-sufficiency, and removed all doubts about its legitimacy and institutional sustainability.

\section{Discussion and conclusion}

The successive cycles of community visioning and strategic planning resulted in creating a social learning environment enabling stakeholders to participate actively in the assessment of water access constraints, and to analyze the impact of current water sharing practices on access inequity. The most effective results were reached in the Kapilaler irrigated area, where the process resulted in a real reform of the water sharing rules within the irrigated area and the creation of a new management association likely to enforce water allocation rules, organize maintenance, and develop competitive cropping systems.

The impact assessment confirms that the participatory approach used was appropriate for tackling a situation of conflict between water users arising from water shortage, when recommended preconditions of success (Gunton and Day, 2003) are there, namely:

- commitment of decision-making agencies to a participatory approach;

- commitment of all stakeholders;

- urgency for resolution of an issue, absence of fundamental value difference, existence of feasible solutions.

As illustrated by Gurung et al. (2006), the combination of participatory appraisal findings and modeling tools showed its capacity to ease a community visioning and planning process. The modeling tool gave an overall picture of the situation and put water conflict in context. It illustrated how benefits could be generated from new water allocation rules and then pushed parties towards a focus on sharing benefits, rather than simply sharing flows.

The initial CVSP cycle, which was the first contact of the project with the community, pointed out that something as a general agreement to discuss issues of concern to all water users could serve as the necessary building block for wider and more substantial decisions and agreements. 
Conversely, there is a potential risk that participants drop out the participative process when issues go beyond the perception of their ability to influence the outcome. In the presented project, this risk materialized into the farmers' engagement in smaller scale activities (in Kapilaler schemes) where the pay-off was nearly immediate. The learning experience provided by this successful local case study then led the actors to agree about water crisis key drivers at the watershed scale, despite their previous skepticism about possible ways forward at this scale. This finding brings to the fore, the key role played by learning acknowledgement to achieve the main objective of supporting collective decisions. Another relevant outcome of the process was to show how the improved learning strongly channeled the sequence of issues focused by the CVSP. Learning was all the more important since the post conflict environment brought stakeholders to first ensure their commitment to the CVSP before exploring a variety of possibilities and deciding what to do.

Regarding the relationship between information sharing and learning process, the way participatory appraisals are conducted plays a key role. The monitoring committees members took ownership of the results while valorizing their knowledge and building their analysis capacity. Community meetings systematically organized to validate results allowed making them unquestionable. That process implicitly led monitoring committee members to form an advocacy group who highly contributed to knowledge dissemination, facilitated debates within the multi-stakeholders platform, and in the end reinforced the legitimacy of the whole process (Barnaud et al., 2016).

Through the CVSP approach that leads to a social learning environment, the major result is definitively the strengthening of stakeholders' empowerment and negotiation capacities reflected by the on-going self-development of the farmers' association FK PADIKA created from the stakeholder driven approach.

Acknowledgements. This research was funded by Danone-Aqua Pt Ltd Indonesia through the project on sustainable water management to improve the access condition to water and its agrarian utilization in one irrigated area located in the downstream zone of the well exploited by the Company in Klaten Regency (Central Java). We are grateful to the two anonymous referees for their useful and constructive suggestions.

\section{References}

Al'Afghani MM. 2006. Constitutional Court's Review and future of water Law in Indonesia. Law Environment and Development Journal (LEAD) 2(1): 18. Available from http://www.eldis.org/ vfile/upload/1/document/0708/DOC22205.pdf.

Badan Pusat Statistik Kabupaten Klaten. 2018. Data Strategis Kabupaten Klaten 2010-2016. Klaten, Java, Indonesia. Available from https://klatenkab.bps.go.id/publication/2018/01/24/ 00e494849513a10f516912 cd/data-strategis-kabupaten-klaten2010-2016.html.

Barnaud C, d'Aquino P, Daré W, Mathevet R. 2016. Dispositifs participatifs et asymétries de pouvoir : expliciter et interroger les positionnements. Participations 16: 137-166. Disponible sur https://doi.org/10.3917/parti.016.0137.
Becu N, Perez P, Walker B, Barreteau O, Le Page C. 2003. Agentbased simulation of a small catchment water management in northern Thailand: Description of the CATCHSCAPE model. Ecological Modelling 170: 319-33.

Bourgeois R, Lopez JM, Sosiawan H, Kartiwa B. 2008. Boire ou manger? Boire et manger. Vers une gestion intégrée du Kapilaler de Klaten. 13th IWRA Water Congress Proceedings. Disponible sur http://iwra.org/member/congress/resource/abs865_article.pdf.

Brugnach M, Tagg A, Keil F, de Lange W. 2007. Uncertainty matters: computer models at science-policy interface. Water Resource Management 21: 1075-1090.

Bruns B, Helmi. 1996. Participatory Irrigation Management in Indonesia: Lessons from Experience and Issues for the Future. Background Paper for the National Workshop on Participatory Irrigation Management, November 4-8, 1996, Jakarta.

Bryson JM, Crosby BC, Bryson JK. 2009. Understanding strategic planning and the formulation and implementation of strategic plans as a way of knowing; The contribution of Actor Theory. International Public Management Journal 12(2): 192-207.

Catroux M. 2002. Introduction à la recherche-action : modalités d'une démarche théorique centrée sur la pratique. Recherche et Pratiques Pédagogiques en Langues de Spécialité 21(3): 8-20. Disponible sur https://apliut.revues.org/4276.

Chambers R. 1988. Managing canal irrigation: Practical analysis from South Asia. New-York (USA): Cambridge University Press.

ComMod. 2003. Our companion modeling approach. Journal of Artificial Societies and Social Simulation 6(1). Available from http://jasss.soc.surrey.ac.uk/6/2/1.html.

Costello PJM. 2003. Action research. London (UK): MPG Books.

Douthwaite B, Kuby T, van de Fliertc E, Schulz S. 2003. Impact pathway evaluation: an approach for achieving and attributing impact in complex systems. Agricultural Systems 78: 243-265.

Étienne M. 2012. La modélisation d'accompagnement: une forme particulière de géoprospective. L'Espace Géographique 41(2): 128-137.

Faure G, Gasselin P, Triomphe B, Temple L, Hocdé H. 2010. Innover avec les acteurs du monde rural : la recherche-action en partenariat. Versailles: QUAE-CTA-Presses Agro. Gembloux.

Gummesson E. 1991. Qualitative methods in management research. Newbury Park (CA): Sage Publications.

Gunton TI, Day JC. 2003. The theory and practice of collaborative planning in resource and environmental management. Environment 31(2): 5-19.

Gurung TR, Bousquet F, Trebuil G. 2006. Companion modeling, conflict resolution, and institution building: Sharing irrigation water in the Lingmuteychu watershed, Bhutan. Ecology and Society 11(2): 36 .

Hardin G. 1968. The tragedy of the commons. Science 162: 12431248.

Horlitz T. 2007. The role of model interfaces for participation in water management. Water Resource Management 21: 1075-1090. Available from http://nrm.massey.ac.nz/changelinks/ar_working. html.

Jonsson A, Alkan-Olsson J. 2005. Participatory modelling: (how) can computer generated information affect the "room of action" of local stakeholders? In: ACSIS Nationella Forskankonferens för Kulturstudier, Norrköpping. Available from http://www.ep.liu.se/ecp/ 015/041/ecp015041.pdf.

Lesser EL, Stork J. 2001. Community of practices and organizational performance. IBM Systems Journal 40(4): 831-841.

Lidon B, Sosiawan H, Triomphe B, Van Hoy M. 2017. Gestion intégrée de l'eau en Indonésie: promouvoir de nouvelles pratiques pour éviter les conflits d'usage. Montpellier : Cirad. Disponible sur 
https:/www.cirad.fr/nos-recherches/resultats-de-recherche/2017/ gestion-integree-de-1-eau-en-indonesie-promouvoir-de-nouvellespratiques-pour-eviter-les-conflits-d-usage.

Lopez JM, Bourgeois R, Lidon B, Brault Y, Kartiwa B, Sosiawan H. 2011. From conflict to equity: Handling the challenge of multipurpose use of ground and surface water in Indonesia. In: Proceedings of Ground water conference, Orleans, France, March 2011. Available from http://agritrop.cirad.fr/560601/1/document_560601.pdf.

Magnuszewski P, Sendzimir J, Kronenberg J. 2004. Conceptual modeling for adaptive environmental assessment and management in the Barycz Valley, lower Silesia, Poland. International Journal of Environmental Research and Public Health 2: 84-90.

Mayne J. 2001. Addressing attribution through contribution analysis: Using performance measures sensibly. Canadian Journal of Program Evaluation 16(1): 1-24.

McNiff J, Whitehead J. 2002. Action research: principles and practice. London: RoutledgeFalmer.

Oja SN, Smulyan L. 1989. Collaborative Action Research: A Developmental Process. Volume 7 Social research and educational studies series. London: Falmer Press, 232 p.

Ostrom E. 1990. Governing the commons: The evolution of institutions for collective action. New-York (USA): Cambridge university press, $280 \mathrm{p}$.
Perry CJ. 1996. Quantification and measurement of a minimum of indicators of performance of irrigation systems. Colombo (Sri Lanka): IWMI.

Purwanti Sri P, Jaji A. 2006. Measuring water conflicts potential: a basic principle. Dinamica TEKNIK SIMPIL 6(2): 101-106.

Reason P, Bradbury H (Ed.). 2001. The SAGE handbook of action research. Participative inquiry and practice. London: Sage.

Temple L, Biénabe E, Barret D, Saint-Martin G. 2016. Methods for assessing the impact of research on innovation and development in the agriculture and food sectors. African Journal of Science, Technology, Innovation and Development 8(5-6): 399-410. DOI: 10.1080/20421338.2016.1219484.

Vermillion DL, Samad M, Pusposutardjo S, Arif S, Rochdyanto S. 1999. An assessment of the smallscale irrigation management turnover program in Indonesia. IWMI research report 38. Colombo (Sri Lanka): IWMI.

Voinov A, Bousquet F. 2010. Modelling with stakeholders. Environmental Modelling \& Software 25(11): 1268-1281.

Wade R, Chambers R. 1980. Managing the main system. Canal irrigation's blind spot. Economic and Political Weekly 15(39): A107-A112.

Cite this article as: Lidon B, Lopez J-M, Sosiawan H, Kartiwa B, Triomphe B, Jamin J-Y, Farolfi S, Bourgeois R, Becu N. 2018. Approach and impact of a participatory process for the reorganization of irrigation management: a case study in Indonesia. Cah. Agric. $27: 25006$. 